\title{
Changes in the dose of inhaled steroid affect exhaled nitric oxide levels in asthmatic patients
}

\author{
S.A. Kharitonov, D.H. Yates, K.F. Chung, P.J. Barnes
}

\begin{abstract}
Changes in the dose of inhaled steroid affect exhaled nitric oxide levels in asthmatic patients. S.A. Kharitonov, D.H. Yates, K.F. Chung, P.J. Barnes. (CERS Journals Ltd 1996.

ABSTRACT: An increased concentration of nitric oxide (NO) in the exhaled air of asthmatic patients may reflect inflammation of the airways, and exhaled NO may, therefore, be useful in monitoring asthma control and the optimal use of anti-inflammatory treatment.

We have studied the effect of reducing and then increasing the dose of inhaled steroid on exhaled NO, lung function and symptoms in 14 asthmatic patients treated with twice daily budesonide. Baseline measurements were made at the end of a 2 week run-in period, 2 weeks after the daily dose of budesonide was reduced by $200 \mu \mathrm{g}$ daily, and 2 weeks after the dose was then increased by $200 \mu \mathrm{g}$ daily.

Exhaled NO increased significantly compared with baseline after the dose was reduced by $200 \mu$ g daily (from $122 \pm 13$ to $246 \pm 52 \mathrm{ppb}$ ); whereas, there was no significant decrease in spirometry or change in peak flow variability. There was also a significant increase in symptoms at night, but no change during the day or in the number of rescue doses of inhaled $\beta_{2}$-agonist. The level of exhaled NO decreased when the dose of inhaled steroids was increased, and this was associated with a reduction in diurnal variability of peak expiratory flow, and in nocturnal symptoms.

Our study suggests that exhaled nitric oxide may be a useful means of monitoring control of asthma. Further longitudinal studies in patients of differing asthma severity are now indicated.
\end{abstract}

Eur Respir J., 1996, 9, 196-201.

Dept of Thoracic Medicine, National Heart and Lung Institute, Dovehouse Street, London, UK.

\section{Correspondence: P.J. Barnes}

Dept of Thoracic Medicine

National Heart and Lung Institute Dovehouse Street

London SW3 6LY

UK

Keywords: Airway inflammation asthma

inducible nitric oxide synthase nitric oxide

steroids

Received: July 171995

Accepted after revision November 71995

This work was supported by National Asthma Campaign (UK), British Lung Foundation and Astra Draco (Sweden).
There is now general agreement that inhaled steroids are the most effective treatment for chronic asthma and that they control asthma by suppressing eosinophilic inflammation in the airways [1]. Inhaled steroids are now recommended for the treatment of asthma in any patients who need to use an inhaled $\beta_{2}$-agonist more than once daily [2-4]. It is recommended that the dose of inhaled steroid should be increased until asthma symptoms are controlled and lung function is optimal. The dose of inhaled steroid should be stepped down once asthma has been controlled for several months, until the minimal dose that maintains control is achieved. Asthma control is normally monitored by frequency of symptoms, inhaled $\beta_{2}$-agonist use or by measurement of serial peak expiratory flow (PEF). However, these clinical measurements may not reflect the degree of airway inflammation, and it may, therefore, be difficult to determine whether the prescribed dose of inhaled steroid is adequate to control asthmatic inflammation. Inflammation in the airways may be reflected by increased airway responsiveness to inhaled histamine or methacholine. Inhaled glucocorticoids reduce airway hyperresponsiveness, although airway responsiveness rarely returns to normal values and the change with inhaled steroids is often very small (less than one dilution) [5-7]. This indicates that measurement of airway hyperresponsiveness may not be a useful clinical means of following control of asthmatic inflammation.

Recently, asthmatic patients have been found to exhale increased concentrations of nitric oxide (NO) [8-10]. This increase in exhaled NO may reflect the increased expression of the inducible form of NO synthase (iNOS) in epithelial cells of asthmatic patients [11]. Human epithelial cells have been shown to express this enzyme in response to proinflammatory cytokines [12]. There is also an increase in NOS enzyme activity in the lungs of patients with asthma [13]. Furthermore, glucocorticoids inhibit the induction of iNOS in epithelial cells in vitro [12], and in asthmatic patients in vivo [14]. This is reflected by a reduction in exhaled NO in asthmatic patients after oral or inhaled steroids $[15,16]$. This suggests that exhaled NO may be a useful marker of chronic inflammation in the airways, and may also be useful in monitoring the response to anti-inflammatory treatment, such as inhaled steroids. Exhaled NO is a simple noninvasive test that would be applicable to repeated measurements in patients, even when lung function is impaired.

We have, therefore, studied the effect of reducing and then increasing the dose of inhaled steroids on exhaled $\mathrm{NO}$ in asthmatic patients already established on regular inhaled steroid therapy. 


\section{Materials and methods}

\section{Patients}

Fourteen asthmatic patients were studied ( 7 males and 7 females) with a mean age of 34 (range 23-63) yrs. All had clinical features of asthma, with previously documented reversibility of forced expiratory volume in one second (FEV1) of $>15 \%$. All patients had positive skin tests for at least two common aeroallergens (cat dander, house dust mite, grass pollen, Aspergillus fumigatus) and had increased bronchial hyperreactivity to methacholine, defined by a provocative concentration of methacholine causing a $20 \%$ fall in FEV1 $\left(\mathrm{PC}_{20}\right)<8 \mathrm{mg} \cdot \mathrm{mL}^{-1}$ (table $1)$.

All of the patients were receiving regular treatment with inhaled budesonide (Pulmicort, Astra) via a multiple-dose dry powder delivery system (Turbohaler®, Astra) in a dose range of 200-2,000 $\mu \mathrm{g} \cdot \mathrm{day}^{-1}$, and on inhaled $\beta_{2}$-agonists as required for symptom control. There was no history of upper respiratory tract infection for at least 4 weeks before the study and PEF recordings over the 2 weeks prior to study were stable with $<15 \%$ variability. None of the patients were smokers.

\section{Study design}

Two sets of observations were made: the effect of steroid dose reduction by $200 \mu \mathrm{g}(\mathrm{n}=14)$, and the effect of increasing the dose by the same amount $(n=12)$. The duration of the study was 8 weeks and involved an initial assessment and four follow-up visits.

There was a 2 week run-in period with no changes in prescribed treatment, followed by a 2 week period on reduced treatment. The patients were then prescribed their original dose of inhaled steroid and remained on this for a further 2 weeks. They then entered the final 2 week period, during which the dose of inhaled steroid was increased. At each study visit, exhaled NO and lung function were measured. Symptoms scores were recorded throughout the study.

The protocol was approved by the hospital Medical Ethics Committee, and written consent from each patient was obtained.

\section{Lung function}

FEV1 and forced vital capacity (FVC) were measured with a dry spirometer (Vitalograph Ltd, Buckingham, UK). The best value of three manoeuvres was expressed as a percentage of the predicted value.

PC20 was measured by inhalation methacholine challenge, with doubling concentrations of methacholine $(0.06$ to $32 \mathrm{mg} \cdot \mathrm{mL}^{-1}$ ) delivered by dosimeter (Mefar, Bovezzo, Italy), with an output of $100 \mu \mathrm{L}$. The aerosols were inhaled at tidal breathing, wearing a noseclip. A total of five inhalations of each concentration were administered (inhalation time $1 \mathrm{~s}$, breathholding time $6 \mathrm{~s}$ ), and FEV1 was measured $2 \mathrm{~min}$ after the last inhalation, until there was a fall in FEV1 of $20 \%$ compared with the control inhalation $(0.9 \%$ saline solution) or until the maximal concentration was inhaled. The $\mathrm{PC} 20$ value was calculated by interpolation of the logarithmic dose-response curve.

\section{Nitric oxide measurements}

Exhaled NO was measured on a chemiluminescence analyser (Dasibi Environmental Corporation, Glendale,

Table 1. - Clinical characteristics of the patients

\begin{tabular}{|c|c|c|c|c|c|c|c|}
\hline $\begin{array}{l}\mathrm{Pt} \\
\text { No. }\end{array}$ & $\begin{array}{l}\text { Age } \\
\text { yrs }\end{array}$ & Sex & $\begin{array}{c}\text { Atopic } \\
\text { status } \\
+/-\end{array}$ & $\begin{array}{c}\text { Duration } \\
\text { of asthma } \\
\text { yrs }\end{array}$ & $\begin{array}{l}\text { FEV } 1 \\
\% \text { pred }\end{array}$ & $\begin{array}{c}\mathrm{FEV} 1 / \mathrm{FVC} \\
\%\end{array}$ & $\begin{array}{l}\mathrm{PC} 20 \\
\mathrm{mg} \cdot \mathrm{mL}^{-1}\end{array}$ \\
\hline 1 & 27 & M & + & 26 & 98 & 99 & 0.22 \\
\hline 2 & 36 & M & + & 14 & 82 & 105 & 1.74 \\
\hline 3 & 41 & M & - & 8 & 83 & 94 & 0.64 \\
\hline 4 & 34 & M & + & 19 & 105 & 108 & 2.44 \\
\hline 5 & 63 & M & - & 6 & 77 & 92 & - \\
\hline 6 & 42 & $\mathrm{~F}$ & + & 12 & 66 & 86 & - \\
\hline 7 & 24 & F & + & 12 & 82 & 94 & 0.64 \\
\hline 8 & 24 & $\mathrm{~F}$ & + & 4 & 93 & 103 & 2.39 \\
\hline 9 & 24 & M & + & 13 & 69 & 68 & 1.15 \\
\hline 10 & 33 & $\mathrm{~F}$ & + & 25 & 92 & 91 & 0.23 \\
\hline 11 & 27 & M & + & 21 & 114 & 114 & 2.14 \\
\hline 12 & 54 & $\mathrm{~F}$ & + & 49 & 62 & 100 & - \\
\hline 13 & 23 & F & + & 6 & 79 & 91 & 2.21 \\
\hline 14 & 29 & F & + & 27 & 72 & 78 & - \\
\hline Mean & 34 & & & 17 & 84 & 95 & $1.01^{\dagger}$ \\
\hline SEM & \pm 3 & & & \pm 3 & \pm 4 & \pm 3 & \pm 0.29 \\
\hline
\end{tabular}

Pt: patient; FEV 1: forced expiratory volume exhaled in one second; FVC: forced vital capacity; PC20: provocative concentration of methacholine producing a $20 \%$ fall in FEV1. Mean \pm SEM values are presented. $\dagger$ : Geometric mean (+SEM). 
California, USA) sensitive to NO from 2 to 4,000 parts per billion (ppb, by volume), adapted for on-line recording of NO concentration, as described previously [9]. This feature obviates the need for collection in a reservoir, with its variable loss of reactive NO, and gives greater sensitivity and reproducibility. Subjects wore a noseclip and were asked to produce a slow vital capacity manoeuvre over $30-45$ s into wide-bore Teflon tubing. NO was sampled continuously at a rate of 250 $\mathrm{mL} \cdot \mathrm{min}^{-1}$ and the measurement of NO was linear over the range measured. The baseline value at each visit was measured after at least $15 \mathrm{~min}$ of quiet rest. Three successive recordings were made, and the highest value of three readings made at 2 min intervals was used in analysis. Results were displayed on a chart recorder and compared with the signal generated from a calibration mixture of NO (89 ppb) in nitrogen. The area under the curve of concentration traces was highly correlated with the peak value ( $\mathrm{r}=0.98)$; peak values were, therefore, used in all calculations. Ambient air NO was recorded before each breath and subtracted. Exhaled NO was measured at each of six visits (at the beginning and end of the runin and each treatment period).

\section{Symptom maximal diurnal variability}

Diary cards were completed every morning and evening by all patients to record asthma symptoms, PEF, time of taking inhaled corticosteroids and $\beta_{2}$-agonist use. At every visit to the clinic, the information from the selfassessment diary card was collated. The symptom enquiry included assessment of symptoms during the day and night, using a four point scale $(0=$ no symptoms; $3=$ severe symptoms). The scores were added to form an overall score (maximum=9).

Diurnal variability of PEF was calculated as follows:

$\frac{\text { Maximum PEF - Minimum PEF }}{\text { Maximum PEF }} \times 100 \%$

\section{Statistics}

Values of FEV1, FVC, PC20, NO and symptom scores during steroid reduction were compared with values obtained during steroid increase, using Student t-tests for paired observations. Comparisons between groups were made by analysis of variance (ANOVA). All results were expressed as the mean \pm SEM. A p-value of less than 0.05 was considered significant.

\section{Results}

\section{Exhaled NO}

Reduction in the dose of inhaled budesonide in 14 patients from a mean \pm SEM of $714 \pm 152$ to $514 \pm 152 \mu \mathrm{g}$ for 2 weeks was associated with a significant increase in exhaled NO level from $122 \pm 13$ to $246 \pm 52 \mathrm{ppb}(\mathrm{p}<0.05)$ (table 2 and fig. 1). In 12 patients in whom the dose of a)

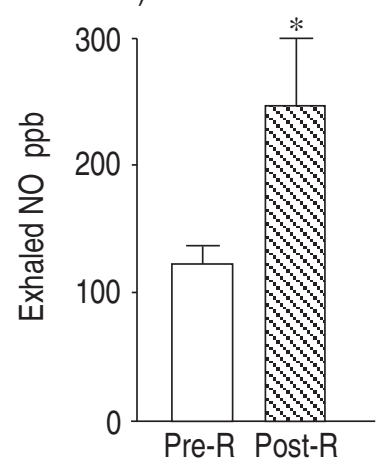

c)

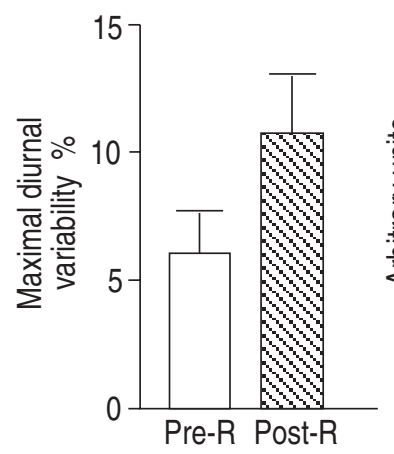

b)

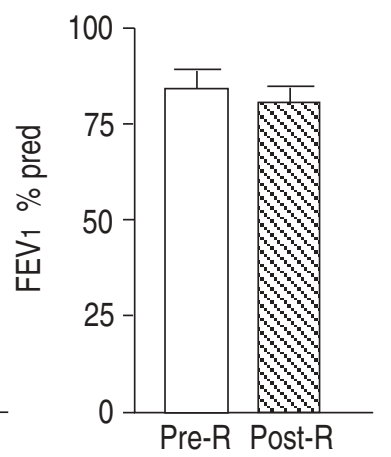

d)

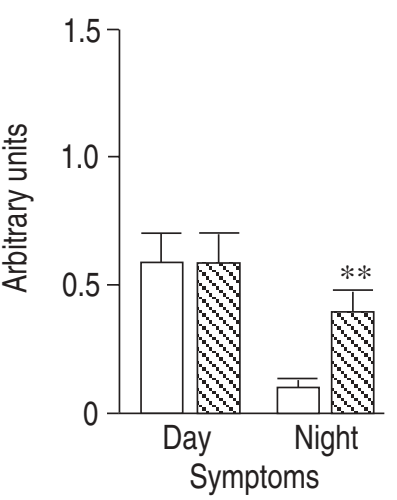

Fig. 1. - Effect of reducing the dose of inhaled steroids in asthmatic patients $(\mathrm{n}=14)$. a) exhaled $\mathrm{NO}$; b) $\mathrm{FEV}_{1}$; c) diurnal variability in PEF; d) asthma symptoms. Values are presented as mean \pm SEM. FEV1: forced expiratory volume in one second; PEF: peak expiratory flow; $\mathrm{R}$ : reduction. $* *$ : $\mathrm{p}<0.001$, compared to baseline.

Table 2. - The effect of reduction in the dose of inhaled budesonide on exhaled nitric oxide, lung function and symptom scores in 14 patients with asthma

\begin{tabular}{|c|c|c|c|c|c|c|c|c|}
\hline & \multirow{2}{*}{$\begin{array}{l}\mathrm{NO} \\
\mathrm{ppb}\end{array}$} & \multirow{2}{*}{$\begin{array}{l}\text { FEV1 } \\
\% \text { pred }\end{array}$} & \multirow{2}{*}{$\begin{array}{l}\mathrm{FVC} \\
\% \text { pred }\end{array}$} & \multirow{2}{*}{$\begin{array}{c}\text { PEF } \\
\text { variability } \\
\%\end{array}$} & \multicolumn{2}{|c|}{ Symptoms scores } & \multirow{2}{*}{$\begin{array}{l}\text { Rescue } \\
\text { medication } \\
\text { puffs } \cdot \text { day }^{-1}\end{array}$} & \multirow{2}{*}{$\begin{array}{c}\text { Budesonide } \\
\mu \mathrm{g} \cdot \mathrm{day}^{-1}\end{array}$} \\
\hline & & & & & Day & Night & & \\
\hline Pre-Red. & $122 \pm 13$ & $84 \pm 4$ & $95 \pm 3$ & $6 \pm 1$ & $0.6 \pm 0.11$ & $0.1 \pm 0.03$ & $2 \pm 0.5$ & $714 \pm 152$ \\
\hline $\begin{array}{l}2 \text { weeks } \\
\text { post-Red. }\end{array}$ & $246 \pm 52 *$ & $80 \pm 4$ & $90 \pm 3$ & $11 \pm 2$ & $0.6 \pm 0.11$ & $0.4 \pm 0.08 * *$ & $3 \pm 0.1$ & $514 \pm 152$ \\
\hline
\end{tabular}

ppb: parts per billion; Day: asthma during the day; Night: asthma last night; PEF variability: maximal diurnal variability of peak expiratory flow rate; Rescue medication: $\beta_{2}$-agonists used; Budesonide: dose of inhaled budesonide. Red.: reduction. For further abbreviations see legend to table 1 . Values are presented as mean \pm SEM. Significant differences $v s$ baseline. $*: \mathrm{p}<0.05 ; * *: \mathrm{p}<0.01$ (analysis of variance (ANOVA), Student's t-test). 
Table 3. - The effect of increase in the dose of inhaled budesonide on exhaled nitric oxide, lung function and symptom scores in 12 patients with asthma

\begin{tabular}{|c|c|c|c|c|c|c|c|c|}
\hline & \multirow{2}{*}{$\begin{array}{l}\mathrm{NO} \\
\mathrm{ppb}\end{array}$} & \multirow{2}{*}{$\begin{array}{l}\text { FEV1 } \\
\% \text { pred }\end{array}$} & \multirow{2}{*}{$\begin{array}{l}\text { FVC } \\
\% \text { pred }\end{array}$} & \multirow{2}{*}{$\begin{array}{c}\text { PEF } \\
\text { variability } \\
\%\end{array}$} & \multicolumn{2}{|c|}{ Symptoms scores } & \multirow{2}{*}{$\begin{array}{l}\text { Rescue } \\
\text { medication } \\
\text { puffs } \cdot \text { day }^{-1}\end{array}$} & \multirow{2}{*}{$\begin{array}{c}\text { Budesonide } \\
\mu \mathrm{g} \cdot \text { day }^{-1}\end{array}$} \\
\hline & & & & & Day & Night & & \\
\hline Pre-I & $167 \pm 25$ & $74 \pm 5$ & $89 \pm 4$ & $12 \pm 2$ & $0.9 \pm 0.18$ & $0.5 \pm 0.16$ & $4 \pm 0.7$ & $800 \pm 152$ \\
\hline $\begin{array}{c}2 \text { weeks } \\
\text { post-I }\end{array}$ & $101 \pm 10 *$ & $79 \pm 3$ & $90 \pm 4$ & $6 \pm 1 *$ & $0.7 \pm 0.17$ & $0.1 \pm 0.04 *$ & $3 \pm 0.1$ & $1117 \pm 164$ \\
\hline
\end{tabular}

Values are presented as mean \pm SEM. Significant differences $v s$ baseline. $*: \mathrm{p}<0.05$ (ANOVA, Student's t-test). I: increase. For further abbreviations see legend to tables 1 and 2 .

a)

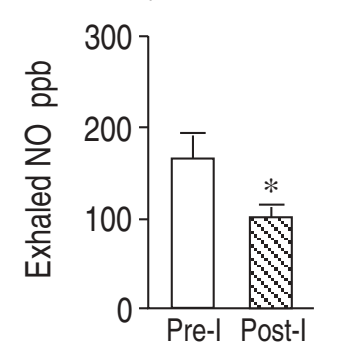

c)

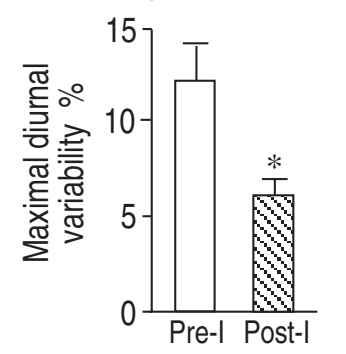

b)

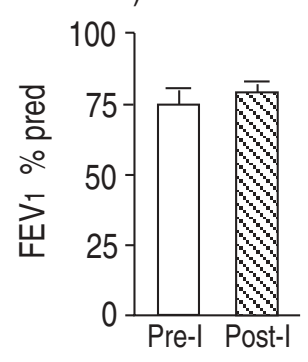

d)

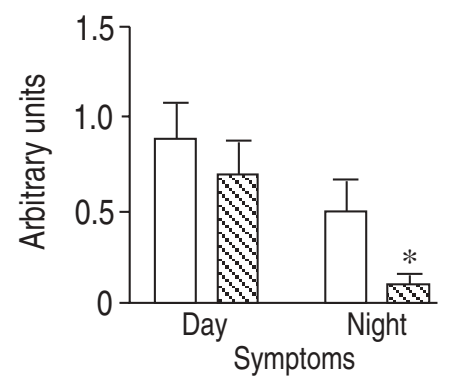

Fig. 2. - Effect of increasing the dose of inhaled steroids in asthmatic patients $(\mathrm{n}=12)$ who had an initial reduction in dose. a) Exhaled $\mathrm{NO}$; b) FEV1; c) diurnal variability; d) symptoms. Values are presented as mean \pm SEM. I: increase; FEV1: forced expiratory volume in one second; ppb: parts per billion. *: $\mathrm{p}<0.05$, compared to baseline.

budesonide was then increased from $800 \pm 152$ to $1,117 \pm 164$ $\mu \mathrm{g}$, the exhaled NO level decreased from $167 \pm 25$ to $101 \pm 10 \mathrm{ppb}(\mathrm{p}<0.05)$ (table 3 and fig. 2) after 2 weeks of treatment. Of the initial 14 patients who completed the steroid reduction limb, two were withdrawn due to development of upper respiratory tract infections.

\section{Lung function}

Lung function and $\beta_{2}$-agonist usage in both treatment groups remained unchanged (FEV1 $84 \pm 4 \%$ predicted prior to steroid reduction and $80 \pm 4 \%$ pred after reduction; FEV $174 \pm 5 \%$ pred prior to steroid increase and $79 \pm$ $3 \%$ after increase in dose (tables 2 and 3, figs. 1 and 2).

\section{Symptoms}

In the group of 14 patients, the reduction in the dose of inhaled budesonide resulted in an increase in clinical scores, but this was not significant, except for nocturnal

symptoms which increased from $0.1 \pm 0.03$ to $0.4 \pm 0.08$ units $(\mathrm{p}<0.001)$ (table 1 , fig. 1). In 12 patients whose dose of budesonide was then increased, symptoms scores were not significantly affected by the change in the treatment, except for diurnal variation $(12 \pm 2 \%$ before and $6 \pm 1 \%$ after $)(\mathrm{p}<0.05)$ (table 2, fig. 2$)$ and nocturnal symptoms $(0.5 \pm 0.16$ before and $0.1 \pm 0.04$ after, $\mathrm{p}<0.05)$. There was no change in the use of inhaled $\beta_{2}$-agonists during any treatment period.

\section{Discussion}

This study has demonstrated that the concentration of NO increases in the exhaled air of asthmatic patients when the dose of inhaled steroids is reduced. This was not accompanied by any change in FEV1 or FVC, and although there was an increase in diurnal variability of PEF, this did not reach statistical significance. There was, however, an increase in asthma symptoms at night, although asthma symptoms during the day did not increase. This suggests that exhaled NO may be a more sensitive index of deterioration in asthma than either symptoms or lung function. Furthermore, when the dose of inhaled steroids was increased again there was a significant reduction in exhaled NO, which returned to baseline values after 2 weeks.

These results suggest that exhaled NO might be a useful means of monitoring inflammation in asthmatic airways. It is likely that inhaled steroids reduce exhaled NO by inhibiting the induction of iNOS in epithelial and inflammatory cells in the airways $[17,18]$. This may be a direct effect on the transcription factors, such as nuclear factor-kappa B $(\mathrm{NF}-\mathrm{k} \beta)$ which increases transcription of the iNOS gene $[19,20]$, or by inhibiting the synthesis of proinflammatory cytokines, such as interleukin-1 $\beta$ (IL$1 \beta)$ and tumour necrosis factor- $\alpha(\mathrm{TNF}-\alpha)$, that may induce iNOS expression in asthma. Reduction in the dose of inhaled steroids presumably allows an increase in proinflammatory cytokines and also has a direct inducing effect on iNOS expression by increasing activation of repressed transcription factors.

In order to monitor the control of asthma it would be desirable to monitor inflammation in the airways. Monitoring of symptoms may be misleading, as bronchodilators relieve symptoms without treating the underlying inflammatory process. Airway hyperresponsiveness has been used as a marker of airway inflammation, but it is relatively difficult to perform in a clinical setting; the changes 
in airway responsiveness after inhaled steroids are modest and even when asthma is optimally controlled the values often remain abnormal. Diurnal variability in peak flow may not accurately reflect airway inflammation and may also be confounded by concomitant treatment with bronchodilators. More direct measurements of airway inflammation include bronchial biopsy, bronchoalveolar lavage and induced sputum. Bronchial biopsies and bronchoalveolar lavage are invasive procedures and are clearly unsuitable for clinical monitoring of inflammation in asthma [21]. Furthermore, it has proved difficult to quantify inflammatory changes in biopsies and lavage fluid. Induced sputum is a useful means of assessing airway inflammation in asthma, but not all patients are able to produce satisfactory samples and there are also problems in quantifying the abnormalities [22].

The measurement of exhaled NO may overcome some of these problems, as the measurement can be made easily in all patients, even when there is severe airflow limitation. Furthermore, the measurement can be repeated in order to study the time course of any treatment or manoeuvre, and the measurement is quantifiable. However, further studies are needed to define the relationship between airway inflammation and exhaled NO. In a recent study of allergen challenge in asthmatic patients, we have demonstrated that exhaled NO increases during the late phase, which is associated with inflammation in the airways, but is not increased during the immediate bronchoconstrictor response to allergen [231.

The source of the NO in exhaled air is still a matter of debate. In normal individuals, exhaled NO may be derived predominantly from the upper respiratory tract $[24,25]$, although studies in perfused pig lungs have suggested that it may also be derived from the alveoli [26]. In asthmatic patients, who show elevated levels of NO in exhaled air, the increase in NO is likely to derive from the lower respiratory tract, as it is reduced by inhaled steroids [16] and inhaled NOS inhibitors [15, 27]. More importantly, direct measurements from the lower respiratory tract via a bronchoscope indicate elevations in exhaled NO in asthmatic patients, with similar values recorded from the lower respiratory tract as in orally exhaled air [28]. It is likely that the increased exhaled NO in asthmatic patients is derived from increased expression of iNOS in airway epithelial cells of asthmatic patients [11]. Furthermore, an inhaled steroid reduces the elevated exhaled NO in asthmatic patients back to normal [16], and is associated with reduced expression of iNOS in epithelial cells of asthmatic patients.

Our study lends further support to the view that exhaled NO may be a useful means of monitoring the control of airway inflammation in asthma. Further controlled longitudinal studies are now needed in asthmatic patients of differing severity in order to confirm this impression. $\mathrm{NO}$ analysers are not widely available at the present time and are expensive. However, in the future it is likely that such devices will be minaturized and will become more widely available. It is even possible to conceive of personal monitors that may be used in conjunction with home peak flow meters. One disadvantage of exhaled NO as a monitor of asthma is that levels are also elevated in the exhaled air in other conditions, such as bronchiectasis and during upper respiratory tract infections [29, 30]. NOS activity in the lung is increased, not only in asthma, but also in cystic fibrosis and obliterative bronchiolitis [13]. Thus, exhaled NO measurements may not be of diagnostic value, but they may be useful in monitoring control of asthma and the response to anti-inflammatory treatments in individual asthmatic patients.

\section{References}

1. Barnes PJ. Inhaled glucocorticoids for asthma. $N$ Engl J Med 1995; 332: 868-875.

2. British Thoracic Society. Guidelines on the management of asthma. Thorax 1993; 48 (Suppl.): S1-S24.

3. National Heart Lung and Blood Institute National Asthma Education Programme Expert Panel Report. Guidelines for the diagnosis and management of asthma. J Allergy Clin Immunol 1991; 88: 425-534.

4. International Consensus Report on Diagnosis and Management of Asthma. Clin Exp Allergy 1992; 22 (Suppl 1): $1-72$.

5. Barnes PJ. Effect of corticosteroids on airway hyperresponsiveness. Am Rev Respir Dis 1990; 141: S70-S76.

6. Juniper EF, Kline PA, Vanzieleghem MA, Ramsdale EH, O'Byrne PM, Hargreave FE. Effect of long-term treatment with an inhaled corticosteroid (budesonide) on airway hyperresponsiveness and clinical asthma in nonsteroid-dependent asthmatics. Am Rev Respir Dis 1990; 142: 832-836.

7. van Essen-Zandvliet EE, Hughes MD, Waalkens HJ, Duiverman EJ, Pocock SJ, Kerrebijn KF. Effects of 22 months of treatment with inhaled corticosteroids and/or beta $_{2}$-agonists on lung function, airway responsiveness and symptoms in children with asthma. Am Rev Respir Dis 1992; 146: 547-554.

8. Alving K, Weitzberg E, Lundberg JM. Increased amount of nitric oxide in exhaled air of asthmatics. Eur Respir $J$ 1993; 6: 1268-1270.

9. Kharitonov SA, Yates D, Robbins RA, Logan-Sinclair $\mathrm{R}$, Shinebourne E, Barnes PJ. Increased nitric oxide in exhaled air of asthmatic patients. Lancet 1994; 343 : 133-135.

10. Persson MG, Zetterstrom O, Argenius V, Ihre E, Gustafsson LE. Single-breath oxide measurements in asthmatic patients and smokers. Lancet 1994; 343: 146-147.

11. Hamid Q, Springall DR, Riveros-Moreno V, et al. Induction of nitric oxide synthase in asthma. Lancet 1993; 342: 1510-1513.

12. Robbins RA, Barnes PJ, Springall DR, et al. Expression of inducible nitric oxide synthase in human bronchial epithelial cells. Biochem Biophys Res Commun 1994; 203: 209-218.

13. Belvisi MG, Barnes PJ, Larkin S, et al. Nitric oxide synthase activity is elevated in inflammatory lung diseases. Eur J Pharmacol 1995; 283: 255-258.

14. Springall DR, Meng Q, Redington A, Howarth PH, Evans TJ, Polak JM. Inducible nitric oxide synthase in asthmatic airway epithelium is reduced by corticosteroid therapy. Am J Respir Crit Care Med 1995; 151: A833.

15. Yates DH, Kharitonov SA, Robbins RA, Thomas PS, Barnes PJ. Effect of a nitric oxide synthase inhibitor and a glucocorticosteroid on exhaled nitric oxide. Am J Respir Crit Care Med 1995; 152(3): 892-896. 
16. Kharitonov SA, Yates DH, Barnes PJ. Regular inhaled budesonide decreases nitric oxide concentration in the exhaled air of asthmatic patients. Am J Respir Crit Care Med 1996; 152: (in press).

17. Barnes PJ Belvisi MG. Nitric oxide and lung disease. Thorax 1993; 48: 1034-1043.

18. Gaston B, Drazen JM, Loscalzo J, Stamler JS. The biology of nitrogen oxides in the airways. Am J Respir Crit Care Med 1994; 149: 538-551.

19. Xie Q, Kashiwarbara Y, Nathan C. Role of transcription factor NF- $\mathrm{KB} / \mathrm{Rel}$ in induction of nitric oxide synthase. J Biol Chem 1994; 269: 4705-4708.

20. Adcock IM, Brown CR, Kwon OJ, Barnes PJ. Oxidative stress induces NF- $\kappa \mathrm{B}$ DNA binding and inducible NOS mRNA in human epithelial cells. Biochem Biophys Res Commun 1994; 199: 1518-1524.

21. Djukanovic R, Roche UR, Wilson JW, et al. Mucosal inflammation in asthma. Am Rev Respir Dis 1990; 142: 434-457.

22. Pin I, Gibson PG, Kolendowicz R, et al. Use of induced sputum cell counts to investigate airway inflammation in asthma. Thorax 1992; 47: 25-29.

23. Kharitonov SA, O'Connor BJ, Evans DJ, Barnes PJ. Allergen-induced late asthmatic reactions are associated with elevation of exhaled nitric oxide. Am J Respir Crit Care Med 1995; 151: 1894-1899.
24. Gerlach H, Rossaint R, Pappert D, Knorr M, Falke KJ. Autoinhalation of nitric oxide after endogenous synthesis in nasopharynx. Lancet 1994; 343: 518-519.

25. Lundberg JON, Weitzberg E, Nordvall SL, Kuylenstierna $\mathrm{R}$, Lundberg JM, Alving K. Primarily nasal origin of exhaled nitric oxide and absence in Kartogener's syndrome. Eur Respir J 1994; 8: 1501-1504.

26. Cremona G, Higenbottam T, Takao M, Hall L, Bower EA. Exhaled nitric oxide in isolated pig lungs. $J$ Appl Physiol 1995; 78: 59-63.

27. Yates DH, Kharitonov SA, Worsdell M, Thomas PS, Barnes PJ. Exhaled nitric oxide is decreased after inhalation of a specific inhibitor of inducible nitric oxide synthase, in asthmatic but not in normal subjects. Am J Respir Crit Care Med 1995; 151: A699.

28. Kharitonov SA, Chung KF, Evans D, O'Connor BJ, Barnes PJ. Increased exhaled nitric oxide in asthma is derived from the lower respiratory tract. Am J Respir Crit Care Med 1996; (in press).

29. Kharitonov SA, Wells AU, O'Connor BJ, Hansell DM, Cole PJ, Barnes PJ. Elevated levels of exhaled nitric oxide in bronchiectasis. Am J Respir Crit Care Med 1995; 151: 1889-1893.

30. Kharitonov SA, Yates D, Barnes PJ. Increased nitric oxide in exhaled air of normal human subjects with upper respiratory tract infections. Eur Respir J 1995; 8: 295-297. 